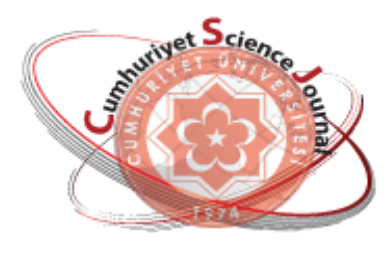

e-ISSN: 2587-246X

ISSN: $2587-2680$

\section{Cumanoriyot Science Journal}

est

Cumhuriyet Sci. J., Vol.38-3 (2017) 461-472

\title{
The Effect of Some Food Preservatives on Percentage of Survival and Longevity in Drosophila melanogaster
}

\author{
Dilek BENLI, Şifa TURKOGLU* \\ Cumhuriyet University, Faculty of Science, Department of Biology, Sivas, Turkey
}

Received: 15.02.2017; Accepted: 17.05.2017

http://dx.doi.org/10.17776/csj.340486

\begin{abstract}
In this study, the toxic effects of ten food preservatives (sorbic acid, potassium sorbate, benzoic acid, sodium benzoate, potassium acetate, sodium metabisulphite, potassium metabisulphite, sodium tetraborate, sodium sulphite and boric acid) on the longevity and percentage of survival were investigated. Wild type of Drosophila melanogaster was used in experiments. Third-instars larvae were treated of the test compounds at concentrations of 5ppm, 10ppm, 15ppm, 20ppm. As a result, all used treatment concentrations were found to reduces the percentage of survival and longevity compared to the control group.
\end{abstract}

Keywords: Drosophila melanogester, food addivities, longevity, percentage of survival.

\section{Bazı Gıda Koruyucularının Drosophila melanogaster'in Yaşama Yüzdesi ve Ömür Uzunluğu Üzerine Etkisi}

\begin{abstract}
Özet: Bu çalışmada 10 farklı gıda koruyucusunun (sorbik asit, potasyum sorbat, benzoik asit, sodyum benzoat, potasyum asetat, sodyum metabisülfit, potasyum metabisüfit, sodyum tetraborat, sodyum sülfit ve borik asit) Drosophila melanogaster'de yaşama yüzdesi ve ömür uzunluğu üzerine olan toksik etkileri araştırılmıştır. Deneylerde Drosophila melanogaster' in yabani tipi kullanılmıştır. Üçüncü dönem larvalara test kimyasalları 5, 10, 15, 20 ppm lik dozlarda uygulanmıştır. Yapılan incelemeler sonunda, kullanılan tüm maddelerin yaşama yüzdesini ve ömür uzunluğunu kontrole nazaran azalttı̆̆ belirlenmiştir
\end{abstract}

Anahtar Kelimeler: Drosophila melanogaster, gıda katkı maddeleri, ömür uzunluğu, yaşama yüzdesi.

\section{INTRODUCTION}

Human beings are often exposed to a wide variety of substances likely to cause toxic, genotoxic or carcinogenic hazards. The most important of all of these substances are food additives. Food additives are contained within a wide variety of products we frequently consume in our daily lives for the purpose of prolonging the shelf life of products, increasing their flavor and preserving them against microorganisms. The use of these additives have been enacted by the laws. However, the consumption of such products in large amounts and for longer periods of time bring with it a number of health problems, as well. It is reported by scientists that several diseases, notably obesity and cancer, are likely to develop particularly in children and in young people in the years ahead who consume such products containing food additives. Food preservatives that have an important place among these food additives are used in many various products. Such substances may be effective in different ways; a. by inhibiting the DNA and protein synthesis by affecting the genetic systems of unwanted microorganisms, b. by causing a cell destabilization by affecting the cell walls and cell membranes of microorganisms, and c. by hindering the reproduction of microorganisms through enzyme inhibition. 
Food preservatives, apart from being used in a great variety of foods, such as dairy products, fruit juice and canned foods, are also used in pharmaceuticals, personal care products (PCPs), cosmetics and other industrial products. Those with the widest area of use are the sorbic acid and salts, benzoic acid and salts, sulfides, nitrites and nitrates, acetates and parabens. Of these substances, the sorbic acid, potassium sorbate, benzoic acid, sodium benzoate, sodium metabisulphite, potassium metabisulphite, sodium sulphide, boric acid, sodium tetraborate and potassium acetate have been preferred as the materials of this study since they are widely used in a number of products that have places in our daily lives.

A number of test methods and model organisms are used in determining the toxic, genotoxic and mutagenic effects of any substance within a living thing. One of these is D. melanogaster, which is an organism used often in genotoxic studies. SMART (somatic mutation and recombination tests), longevity and percentage of survival analyses play an important part in the studies conducted on Drosophila. Drosophila genom sequence analysis has shown that more than $60 \%$ of the genes determined in human diseases were orthologs of Drosophila. In addition to this characteristic, Drosophila is preferred in many genotoxic and mutagenic studies due to the fact that it has a short life cycle, it is easily bred and reproduces in great numbers, and its phenotypic variations can easily be observed [1-3]. Apart from these fields of study, Drosophila is also the model organism often preferred in the researches concerned with the aging process [4-10]. Considering all of these advantages, in our research, Drosophila melanogaster was preferred as the model organism in determining the toxic effects of the food preservatives that are frequently used in the food industry and that we are and will be exposed to all through our lives.

In this study, by applying 5, 10, 15 and 20 ppm doses of 10 different food preservatives, the toxic effects of which we investigated in this study, on the D. melanogaster medium, it was aimed that the effects of these substances on the life span and the percentage of survival be examined and analyzed.

\section{MATERIAL and METHOD}

Flies belonging to the Oregon $\mathrm{R}$ wild-type strain of D. melanogaster were used in the experiments. The stock of this fly had been maintained over several years in the laboratory of the Department of Biology, Cumhuriyet University, Sivas, and is highly inbred with little genetic variation. The flies were maintained at a constant temperature of $25^{\circ} \mathrm{C}$ $\pm 1^{\circ} \mathrm{C}$ on a standard medium composed of maize flour, agar, sucrose, dried yeast, and propionic acid (Standard Drosophila Medium; SDM). The flies were kept in the dark, except during the transfer onto fresh medium (usually twice a week). The humidity of the experimental chamber was 40$60 \%$, and the female flies used in this experiment were virgins.

\section{Chemicals}

- Sorbic acid (E200): CAS no: 110-44-1; $\mathrm{C}_{6} \mathrm{H}_{8} \mathrm{O}_{2} ; 112,13 \mathrm{~g} / \mathrm{mol}$

- Potassium sorbate (E202): CAS no: 2464361-5; $\mathrm{C}_{6} \mathrm{H}_{7} \mathrm{KO}_{2} ; 150,22 \mathrm{~g} / \mathrm{mol}$

- Benzoic acid (E210): CAS no: 65-85-0; $\mathrm{C}_{6} \mathrm{H}_{5} \mathrm{COOH} ; 122,12 \mathrm{~g} / \mathrm{mol}$

- Sodium benzoate (E211): CAS no: 532-32-1; $\mathrm{C}_{6} \mathrm{H}_{5} \mathrm{COONa} ; 144,10 \mathrm{~g} / \mathrm{mol}$

- Sodium metabisulphite (E223): CAS no: 7681- 57-4; $\mathrm{Na}_{2} \mathrm{~S}_{2} \mathrm{O}_{5} ; 190,11 \mathrm{~g} / \mathrm{mol}$

- Potassium metabisulphite (E224): CAS no: 16731-55-8; $\mathrm{K}_{2} \mathrm{O}_{5} \mathrm{~S}_{2} ; 222,32 \mathrm{~g} / \mathrm{mol}$

- $\quad$ Sodium sulphite (E221): CAS no: 7757- 83-7; $\mathrm{Na}_{2} \mathrm{SO}_{3} ; 126.043 \mathrm{~g} / \mathrm{mol}$

- Boric acid (E284): CAS no: 10043-35-3; $\mathrm{H}_{3} \mathrm{BO}_{3} ; 61.83 \mathrm{~g} / \mathrm{mol}$

- Sodium tetraborate (E285): CAS no: 1303-96$4 ; \mathrm{Na}_{2} \mathrm{O}_{2} \mathrm{~B}_{2} \mathrm{O}_{3} ; 381,37 \mathrm{~g} / \mathrm{mol}$

- Potassium asetate (E261): CAS no: 127- 08-2; $\mathrm{CH}_{3} \mathrm{CO}_{2} \mathrm{~K} ; 98,15 \mathrm{~g} / \mathrm{mol}$

All chemicals were obtained from Sigma-Aldrich. 


\section{EXPERIMENTS on LONGEVITY}

The effect of food preservatives on longevity were separately studied on female and male populations. To that end, pre-stocks were formed. Starting from the date when crossbreeding was performed, the parents were taken away on the day the pupa appeared. For each of the experimental groups, an average of 100 individuals were collected out of the unmated $q$ 우 and $\delta \hat{\sigma}$ flies emerging from the pupa, which were of the same age (1-3 days). The collected individuals were put into the empty 250 $\mathrm{ml}$ - culture bottles and were left hungry for 2 hours prior to the application. For the groups of administration/application, a $25 \mathrm{~g}$ of standard medium was placed into each culture bottle and 5 $\mathrm{ml}$ of food preservatives prepared at different concentrations were added onto it. The individuals taken into the administration bottles were left within this medium for 2 hours.

Following the application, 100 individuals gathered in a single bottle for the applications were separated as 25 individuals each $(q Q+q$ and $\hat{\partial} \widehat{\delta}$ separately) by being put into the culture bottles which had a standard medium within. Throughout the experiment, the nutrients were refreshed twice a week (on Mondays and Thursdays). The number of the individuals were checked at the beginning and end of each application day, and the perished individuals were recorded and then removed from the medium. This practice was continued in each experimental and control group until the last individual within the group perished.

\section{EXPERIMENTS on the PERCENTAGE of SURVIVAL}

3 days after crossbreeding the 5-day-virgin females and the males of the same age obtained from the Drosophila cultures, third instar larvae were obtained from the eggs collected at 4-hourintervals. For the administration groups, a $10 \mathrm{~g}$ of medium was put into each culture bottle, and $6 \mathrm{ml}$ of food preservatives prepared at different concentrations was added onto it. The larvae taken from the standard nutrient media and then washed up were buried in groups of 100 into the chemicaladded mediums. The larvae taken into the standard instant mediums containing chemicals were left to complete their developmental stage. The mature individuals emerging from the pupas were etherized under the dissection microscope according to their genders and phenotypes. Each dose administration was repeated three times. The count lasted for seven days, starting from the time when the first individual emerged from the pupa.

\section{Statistic}

The data obtained were analyzed by using SPSS (version 15.0). One-way analysis of variance and Duncan's multiple-range test were used for the mean longevity values of the control and applications groups.

\section{RESULTS}

In the present study, the changes in the longevity of D. melanogaster, which were exposed to food preservatives at different treatment doses, were investigated. The lethal concentration $50\left(\mathrm{LC}_{50}\right)$ value for these preservatives was $30 \mathrm{ppm}$. The concentrations below the $\mathrm{LC}_{50}$ value, namely, 5,10 , 15 and $20 \mathrm{ppm}$ were tested in the experiments. Tables 1 and Figures 1 and 2 show the effect of different concentrations of sorbic acid, potassium sorbate, benzoic acid, sodium benzoate, potassium metabisulphite, sodium metabisulphite, sodium sulphide, boric acid, sodium tetraborate and potassium acetate on longevity. In this study, we determined that these food preservatives decreased the maximum mean life-span of the female and male D. melanogaster populations in comparison with the control groups not exposed to the chemicals. The maximum life span of this fly was 50-68 days for the female flies and 54-64 days for the male flies in the control groups. For female flies, the difference between the control and application groups was statistically significant $(p<0.05)$ exposed to sorbic acid, potassium sorbate, benzoic acid, potassium metabisulphite, sodium metabisulphite, sodium sulphide, boric acid, sodium tetraborate and potassium acetate. However, for sodium benzoate, there was no significant difference between maximum life span of the female flies from the control group and 5 ppm application group. For the male flies, the difference between the control and the other 
application goups was statistically significant to exposed to nine food preservatives (Except for boric acid).

In D. melanogaster, the effects of food preservatives on the percentage of survival are seen in Table 2 and Figure 2. When the survival percentages of $D$. melanogaster individuals in the experimental groups are compared with those in the control groups, it was ascertained that there were statistically significant differences between them. The substances that were examined and studied generally minimized the survival percent when compared with the control groups, which, however, did not take place in parallel to the dose increase. As will also be seen from the table, there is no difference between the control groups and the others, except for that $10 \mathrm{ppm}$ - dose of potassium acetate.

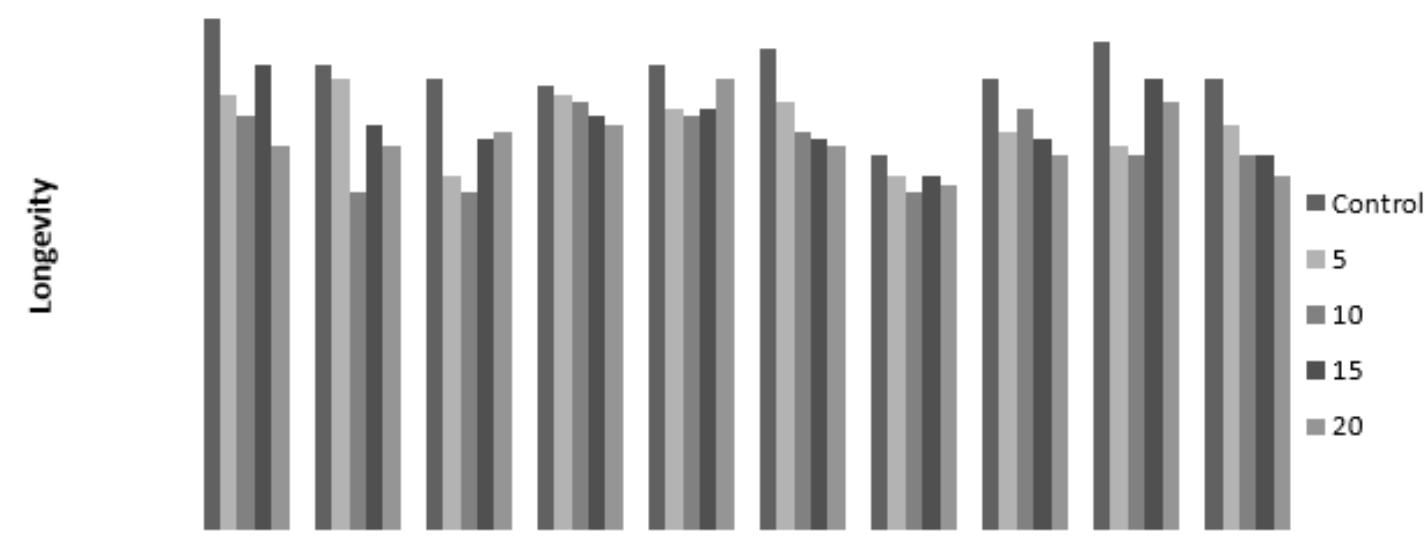

Chemicals

Figure 1. The maximum longevity column of female individuals the D. melanogaster living medium applied with different concentrations of food preservatives during adult stages (S. A.: Sorbic Acid, P. S.: Potassium Sorbate, Bz. A.: Benzoic Acid, S. B.: Sodium Benzoate, S. M.: Sodium Metabisulphite, P. M.: Potassium Metabisulphite, B. A.: Boric Acid, S. T.: Sodium Tetraborate, S. S.: Sodium Sulphide, P. A.: Potassium Acetate).

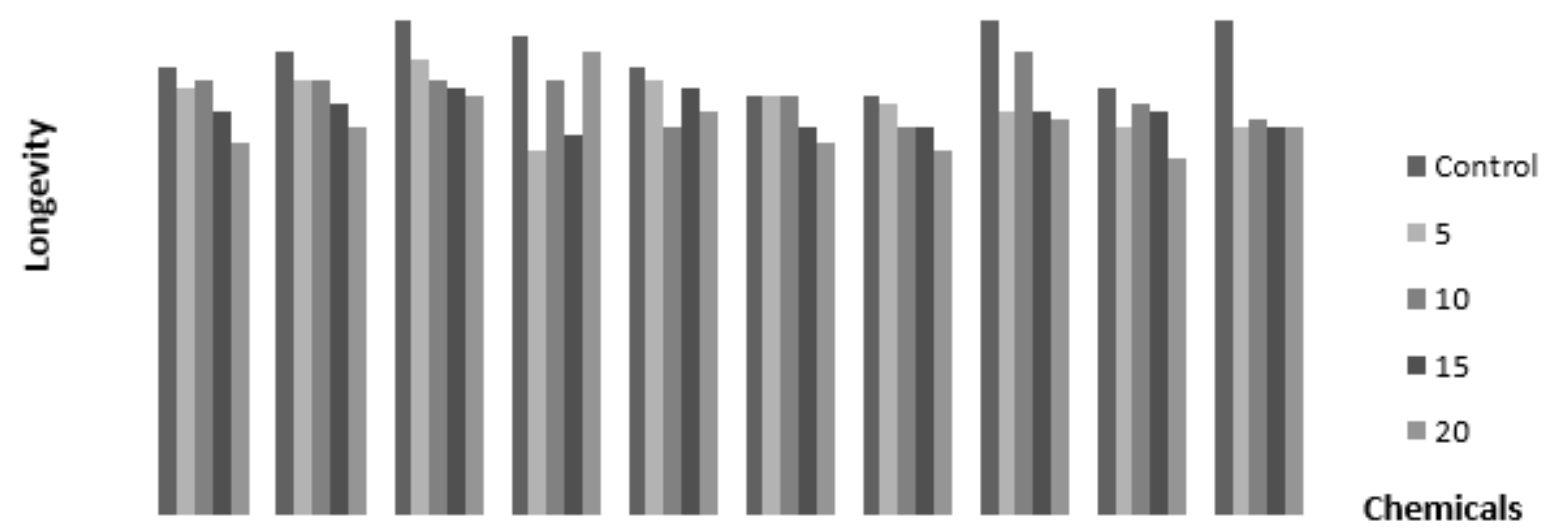

Figure 2. The maximum longevity column of male individuals the D. melanogaster living medium applied with different concentrations of food preservatives during adult stages (S. A.: Sorbic Acid, P. S.: Potassium Sorbate, Bz. A.: Benzoic Acid, S. B.: Sodium Benzoate, S. M.: Sodium Metabisulphite, P. M.: Potassium Metabisulphite, B. A.: Boric Acid, S. T.: Sodium Tetraborate, S. S.: Sodium Sulphide, P. A.: Potassium Acetate). 
Table 1. Effects of food preservatives on longevity of D. melanogaster.

\begin{tabular}{|c|c|c|c|c|}
\hline Chemicals & $\begin{array}{l}\text { Doses } \\
\text { (ppm) }\end{array}$ & Number of flies & Max. life span $(+)^{*}$ & Max. life span $\left({ }^{\Uparrow}\right)^{*}$ \\
\hline \multirow[t]{5}{*}{ Sorbic acid } & Control & 100 & $68 \mathrm{a}$ & $58 \mathrm{a}$ \\
\hline & 5 & 100 & $58 \mathrm{~b}$ & $55 \mathrm{~b}$ \\
\hline & 10 & 100 & $55 \mathrm{c}$ & $56 \mathrm{~b}$ \\
\hline & 15 & 100 & $62 \mathrm{~d}$ & $52 \mathrm{c}$ \\
\hline & 20 & 100 & $51 \mathrm{e}$ & $52 \mathrm{c}$ \\
\hline \multirow[t]{5}{*}{ Potassium sorbate } & Control & 100 & $62 \mathrm{a}$ & $56 \mathrm{a}$ \\
\hline & 5 & 100 & $60 \mathrm{~b}$ & $50 \mathrm{~b}$ \\
\hline & 10 & 100 & $45 \mathrm{c}$ & $50 \mathrm{~b}$ \\
\hline & 15 & 100 & $54 \mathrm{~d}$ & $53 \mathrm{c}$ \\
\hline & 20 & 100 & $51 \mathrm{e}$ & $53 \mathrm{c}$ \\
\hline \multirow[t]{5}{*}{ Benzoic acid } & Control & 100 & $60 \mathrm{a}$ & $64 \mathrm{a}$ \\
\hline & 5 & 100 & $47 \mathrm{~b}$ & $55 \mathrm{~b}$ \\
\hline & 10 & 100 & $45 \mathrm{c}$ & $59 \mathrm{c}$ \\
\hline & 15 & 100 & $52 \mathrm{~d}$ & $47 \mathrm{~d}$ \\
\hline & 20 & 100 & $53 \mathrm{~d}$ & $56 \mathrm{~b}$ \\
\hline \multirow[t]{5}{*}{ Sodium benzoate } & Control & 100 & 59 a & $62 \mathrm{a}$ \\
\hline & 5 & 100 & $58 \mathrm{ab}$ & $47 \mathrm{~b}$ \\
\hline & 10 & 100 & $57 \mathrm{~b}$ & $56 \mathrm{c}$ \\
\hline & 15 & 100 & $55 \mathrm{c}$ & $49 \mathrm{~d}$ \\
\hline & 20 & 100 & $54 \mathrm{c}$ & $60 \mathrm{e}$ \\
\hline \multirow[t]{5}{*}{ Sodium metabisulphite } & Control & 100 & $62 \mathrm{a}$ & 58 a \\
\hline & 5 & 100 & $56 \mathrm{~b}$ & $56 \mathrm{~b}$ \\
\hline & 10 & 100 & $55 \mathrm{~b}$ & $50 \mathrm{c}$ \\
\hline & 15 & 100 & $56 \mathrm{~b}$ & $55 \mathrm{~b}$ \\
\hline & 20 & 100 & $60 \mathrm{c}$ & $52 \mathrm{~d}$ \\
\hline \multirow[t]{5}{*}{ Potassium metabisulphite } & Control & 100 & $64 \mathrm{a}$ & $54 \mathrm{a}$ \\
\hline & 5 & 100 & $57 \mathrm{~b}$ & $54 \mathrm{~b}$ \\
\hline & 10 & 100 & $53 \mathrm{c}$ & $54 \mathrm{~b}$ \\
\hline & 15 & 100 & $52 \mathrm{~cd}$ & $50 \mathrm{~b}$ \\
\hline & 20 & 100 & $51 \mathrm{~d}$ & $48 \mathrm{c}$ \\
\hline \multirow[t]{5}{*}{ Boric acid } & Control & 100 & $50 \mathrm{a}$ & $54 \mathrm{a}$ \\
\hline & 5 & 100 & $47 \mathrm{~b}$ & $53 \mathrm{a}$ \\
\hline & 10 & 100 & $45 \mathrm{~cd}$ & $50 \mathrm{~b}$ \\
\hline & 15 & 100 & $47 \mathrm{~b}$ & $50 \mathrm{~b}$ \\
\hline & 20 & 100 & $46 \mathrm{bd}$ & $47 \mathrm{c}$ \\
\hline \multirow[t]{5}{*}{ Sodium tetraborate } & Control & 100 & $60 \mathrm{a}$ & $64 \mathrm{a}$ \\
\hline & 5 & 100 & $53 \mathrm{~b}$ & $52 \mathrm{~b}$ \\
\hline & 10 & 100 & $56 \mathrm{c}$ & $60 \mathrm{c}$ \\
\hline & 15 & 100 & $52 \mathrm{~b}$ & $52 \mathrm{~b}$ \\
\hline & 20 & 100 & $50 \mathrm{~d}$ & $51 \mathrm{~b}$ \\
\hline \multirow[t]{5}{*}{ Sodium sulphite } & Control & 100 & $65 \mathrm{a}$ & $55 \mathrm{a}$ \\
\hline & 5 & 100 & $51 \mathrm{~b}$ & $50 \mathrm{~b}$ \\
\hline & 10 & 100 & $50 \mathrm{~b}$ & $53 \mathrm{c}$ \\
\hline & 15 & 100 & $60 \mathrm{c}$ & $52 \mathrm{c}$ \\
\hline & 20 & 100 & $57 \mathrm{~d}$ & $46 \mathrm{~d}$ \\
\hline \multirow[t]{5}{*}{ Potassium asetate } & Control & 100 & $60 \mathrm{a}$ & $64 \mathrm{a}$ \\
\hline & 5 & 100 & $54 \mathrm{~b}$ & $50 \mathrm{~b}$ \\
\hline & 10 & 100 & $50 \mathrm{c}$ & $51 \mathrm{~b}$ \\
\hline & 15 & 100 & $50 \mathrm{c}$ & $50 \mathrm{~b}$ \\
\hline & 20 & 100 & $47 \mathrm{~d}$ & $60 \mathrm{c}$ \\
\hline
\end{tabular}

* S. E.: Standart Error, Max.: maximum

Means with the same letters do not significantly differ at 0.05 level. 
Table 2. Effects of food preservatives on survival percentage of D. melanogaster.

\begin{tabular}{|c|c|c|c|c|c|c|}
\hline \multirow[t]{2}{*}{ Chemicals } & \multirow{2}{*}{$\begin{array}{l}\text { Doses } \\
(\mathrm{ppm})\end{array}$} & \multicolumn{2}{|c|}{ Number of flies } & \multirow{2}{*}{$\begin{array}{c}\text { Female } \\
(())\end{array}$} & \multirow{2}{*}{$\begin{array}{l}\text { Male } \\
\left(\delta^{\lambda}\right)\end{array}$} & \multirow[t]{2}{*}{$\operatorname{Mean} \pm$ S. E. * } \\
\hline & & ㅇ & $\hat{0}$ & & & \\
\hline \multirow[t]{5}{*}{ Sorbic acid } & Control & 100 & 100 & $30 \pm 0.32$ & $39 \pm 0.17$ & $69 \pm 0.30 \mathrm{a}$ \\
\hline & 5 & 100 & 100 & $21 \pm 0.22$ & $19 \pm 0.19$ & $40 \pm 1.22 \mathrm{~b}$ \\
\hline & 10 & 100 & 100 & $19 \pm 0.13$ & $20 \pm 0.21$ & $39 \pm 1.39 b$ \\
\hline & 15 & 100 & 100 & $9 \pm 0.18$ & $11 \pm 0.29$ & $20 \pm 1.27 \mathrm{c}$ \\
\hline & 20 & 100 & 100 & $15 \pm 0.24$ & $15 \pm 0.05$ & $30 \pm 1.00 \mathrm{~d}$ \\
\hline \multirow[t]{5}{*}{ Potassium sorbate } & Control & 100 & 100 & $39 \pm 1.23$ & $26 \pm 2.41$ & $65 \pm 0.52 \mathrm{a}$ \\
\hline & 5 & 100 & 100 & $28 \pm 2.56$ & $24 \pm 1.23$ & $52 \pm 0.25 \mathrm{~b}$ \\
\hline & 10 & 100 & 100 & $17 \pm 1.63$ & $32 \pm 1.30$ & $49 \pm 0.28 \mathrm{c}$ \\
\hline & 15 & 100 & 100 & $27 \pm 1.07$ & $26 \pm 1.09$ & $53 \pm 1.38 \mathrm{~b}$ \\
\hline & 20 & 100 & 100 & $24 \pm 1.27$ & $19 \pm 1.17$ & $43 \pm 0.44 \mathrm{e}$ \\
\hline \multirow[t]{5}{*}{ Benzoic acid } & Control & 100 & 100 & $32 \pm 0.48$ & $32 \pm 0.29$ & $64 \pm 0.16 \mathrm{a}$ \\
\hline & 5 & 100 & 100 & $19 \pm 0.90$ & $23 \pm 0.40$ & $42 \pm 0.64 b$ \\
\hline & 10 & 100 & 100 & $27 \pm 0.23$ & $26 \pm 0.50$ & $53 \pm 0.50 \mathrm{c}$ \\
\hline & 15 & 100 & 100 & $27 \pm 0.25$ & $26 \pm 0.29$ & $53 \pm 0.39 \mathrm{c}$ \\
\hline & 20 & 100 & 100 & $27 \pm 0.85$ & $23 \pm 0.66$ & $50 \pm 0.16 \mathrm{~d}$ \\
\hline \multirow[t]{5}{*}{ Sodium benzoate } & Control & 100 & 100 & $35 \pm 1.03$ & $38 \pm 0.02$ & $73 \pm 2.41 \mathrm{a}$ \\
\hline & 5 & 100 & 100 & $38 \pm 0.44$ & $29 \pm 1.04$ & $67 \pm 1.05 \mathrm{~b}$ \\
\hline & 10 & 100 & 100 & $31 \pm 0.37$ & $20 \pm 2.36$ & $51 \pm 0.85 \mathrm{c}$ \\
\hline & 15 & 100 & 100 & $27 \pm 0.87$ & $31 \pm 1.97$ & $58 \pm 1.13 \mathrm{~d}$ \\
\hline & 20 & 100 & 100 & $26 \pm 0.77$ & $25 \pm 0.93$ & $51 \pm 0.32 \mathrm{c}$ \\
\hline \multirow[t]{5}{*}{ Sodium metabisulphite } & Control & 100 & 100 & $24 \pm 0.10$ & $30 \pm 0.13$ & $54 \pm 0.60 \mathrm{a}$ \\
\hline & 5 & 100 & 100 & $22 \pm 0.36$ & $24 \pm 0.10$ & $46 \pm 0.30 \mathrm{~b}$ \\
\hline & 10 & 100 & 100 & $29 \pm 0.09$ & $28 \pm 0.19$ & $57 \pm 0.21 \mathrm{c}$ \\
\hline & 15 & 100 & 100 & $15 \pm 0.17$ & $14 \pm 0.11$ & $29 \pm 0.25 \mathrm{~d}$ \\
\hline & 20 & 100 & 100 & $25 \pm 0.09$ & $21 \pm 0.05$ & $46 \pm 0.10 \mathrm{~b}$ \\
\hline \multirow[t]{5}{*}{ Potassium metabisulphite } & Control & 100 & 100 & $31 \pm 1.20$ & $32 \pm 1.19$ & $63 \pm 1.10 \mathrm{a}$ \\
\hline & 5 & 100 & 100 & $31 \pm 0.13$ & $31 \pm 1.27$ & $62 \pm 1.21 \mathrm{ac}$ \\
\hline & 10 & 100 & 100 & $30 \pm 0.30$ & $24 \pm 1.21$ & $54 \pm 1.30 \mathrm{~b}$ \\
\hline & 15 & 100 & 100 & $30 \pm 1.41$ & $23 \pm 0.13$ & $53 \pm 1.42 \mathrm{~b}$ \\
\hline & 20 & 100 & 100 & $31 \pm 1.00$ & $30 \pm 1.28$ & $61 \pm 1.16 \mathrm{c}$ \\
\hline \multirow[t]{5}{*}{ Boric acid } & Control & 100 & 100 & $34 \pm 0.30$ & $39 \pm 0.48$ & $73 \pm 0.27 \mathrm{a}$ \\
\hline & 5 & 100 & 100 & $26 \pm 0.55$ & $29 \pm 0.92$ & $55 \pm 1.43 \mathrm{~b}$ \\
\hline & 10 & 100 & 100 & $32 \pm 1.51$ & $29 \pm 1.44$ & $61 \pm 2.16 \mathrm{c}$ \\
\hline & 15 & 100 & 100 & $28 \pm 1.93$ & $34 \pm 1.19$ & $62 \pm 1.22 \mathrm{c}$ \\
\hline & 20 & 100 & 100 & $28 \pm 2.00$ & $29 \pm 2.76$ & $57 \pm 2.34 \mathrm{~d}$ \\
\hline \multirow[t]{5}{*}{ Sodium tetraborate } & Control & 100 & 100 & $38 \pm 1.14$ & $31 \pm 1.11$ & $69 \pm 2.01 \mathrm{a}$ \\
\hline & 5 & 100 & 100 & $30 \pm 2.08$ & $36 \pm 0.57$ & $66 \pm 1.78 \mathrm{~b}$ \\
\hline & 10 & 100 & 100 & $36 \pm 1.58$ & $27 \pm 1.42$ & $63 \pm 1.43 \mathrm{c}$ \\
\hline & 15 & 100 & 100 & $33 \pm 1.06$ & $28 \pm 1.93$ & $61 \pm 1.59 \mathrm{~d}$ \\
\hline & 20 & 100 & 100 & $28 \pm 1.29$ & $24 \pm 2.01$ & $52 \pm 1.21 \mathrm{e}$ \\
\hline \multirow[t]{5}{*}{ Sodium sulphite } & Control & 100 & 100 & $35 \pm 1.22$ & $28 \pm 3.41$ & $63 \pm 1.21 \mathrm{a}$ \\
\hline & 5 & 100 & 100 & $20 \pm 1.47$ & $16 \pm 2.16$ & $36 \pm 1.75 \mathrm{~b}$ \\
\hline & 10 & 100 & 100 & $29 \pm 1.35$ & $26 \pm 1.56$ & $55 \pm 1.34 \mathrm{c}$ \\
\hline & 15 & 100 & 100 & $20 \pm 0.19$ & $28 \pm 2.05$ & $48 \pm 2.09 \mathrm{~d}$ \\
\hline & 20 & 100 & 100 & $35 \pm 2.18$ & $20 \pm 1.46$ & $55 \pm 2.17 \mathrm{c}$ \\
\hline \multirow[t]{5}{*}{ Potassium asetate } & Control & 100 & 100 & $27 \pm 1.14$ & $25 \pm 1.21$ & $52 \pm 1.23 \mathrm{a}$ \\
\hline & 5 & 100 & 100 & $27 \pm 1.58$ & $25 \pm 1.38$ & $52 \pm 2.25 \mathrm{a}$ \\
\hline & 10 & 100 & 100 & $23 \pm 1.37$ & $21 \pm 2.54$ & $50 \pm 1.52 \mathrm{~b}$ \\
\hline & 15 & 100 & 100 & $23 \pm 2.48$ & $27 \pm 1.23$ & $52 \pm 1.51 \mathrm{a}$ \\
\hline & 20 & 100 & 100 & $28 \pm 1.06$ & $24 \pm 1.97$ & $52 \pm 1.98 \mathrm{a}$ \\
\hline \multicolumn{7}{|c|}{$\begin{array}{l}\text { * S. E.: Standart Error, } \\
\text { * Means with the same letters do not } \\
\text { Significantly differ at } 0.05 \text { level. }\end{array}$} \\
\hline
\end{tabular}




\section{DISCUSSION and CONCLUSION}

In this study, the effects of the food preservatives used in foods and various cosmetic products, such as sorbic acid, potassium sorbate, benzoic acid, sodium benzoate, potassium metabisulphite, sodium metabisulphite, sodium sulphide, boric acid, sodium tetraborate and potassium acetate, on the longevity and percentage of survival of $D$. melanogaster were investigated.

In a study conducted by Sarıaya and Solak [11], where the genotoxic effect of benzoic acid on $D$. melanogaster was researched through the somatic mutation and recombination tests, it was stated that there had been an increase in the wing mutations of D. melanogaster with the different concentrations of the chemical in question. In another study performed by Sarıkaya and Çakır [12], the genotoxic effects of 4 food preservatives on Drosophila were examined via SMART, and all the chemicals used in this process were determined to have shown a toxic effect. Sarıkaya et al., [7] researched into the effects of sodium nitrite, sodium nitrate, potassium nitrite and potassium nitrate on the length of life in Drosophila, and as the result of the study, the substance with the lowest rate of life span was determined to be sodium nitrite.

It was suggested by Stallings et al., [13] that the chromium picolinate in $D$. melanogaster had caused a decrease in the number of mature individuals, a decline in the length of life and anomalies in polytene chromosomes.

Demir et al., [14] researched into the effects of benzyl alcohol used as a food additive on $D$. melanogaster, and determined that the concentration of $50 \mathrm{mM}$ had led to mutation.

Erciyas and Sarıkaya [15] applied the SMART method in order to investigate the genotoxic effect of sodium fluoride, and as the result of the study, they determined that this substance had shown toxic and genotoxic effects at 5 and $10 \mathrm{~g} / \mathrm{ml}$ doses. In another study conducted on food dyes, the effects of 5 food dyes at different concentrations on the survival percent of $D$. melanogaster were investigated by Sarkkaya [16] and of these dyes, erythrosine was suggested to have affected the longevity more than the others.

On the other hand, in another study conducted by Deepa et al., [17] the effect of benzaldehyde -which is used to give aroma to foods- on D. melanogaster was examined via SMART, and as the result of the study, this substance was determined to have mutagenic and genotoxic effects.

In this study we have conducted, the data obtained for the percentage of survival and the longevity can be seen in the Tables 1-2 and Figures 1-2. Whereas, in some groups of administration, the control group had the highest percentage of survival and the longevity, this condition seemed to be the other way round in some others. The female individuals had more longevity compared to the male ones. When the data are examined and analyzed, the substance with the most impact on the longevity is sorbic acid for the female ones, whereas that substance for the male ones is sodium benzoate. The substances with the least impact, on the other hand, are potassium acetate in females and potassium metabisulphite in males. Of the substances we used, the sorbic acid had the greatest impact on the survival percent of females, whereas the substance with the greatest impact in males was sodium benzoate. It was seen that potassium sulphate in females had the least impact on their survival percent, whereas in males, potassium acetate had an impact in the same direction.

Considering the factors affecting longevity and percentage of survival, the outside factors, such as temperature, nutrition, radiation and population density are effective in Drosophila as well as the inner factors like maternal age, fecundity, micro and macrogametes and genetic structure $[18,19$, 20].

The metabolic rates of poikilothermic living creatures, particularly insects, are greatly affected by the environmental temperature. The longevity 
of such creatures are shortened by the fact that the environmental temperature rises up. In other words, the longevity and temperature are inversely correlated [19, 21, 22].

Economus and Lints [23] reported that the optimum temperature range for female and male Drosophila individuals was between $16-29^{\circ} \mathrm{C}$, and that the number of mortalities below $12{ }^{\circ} \mathrm{C}$ and also below and above $32,5^{\circ} \mathrm{C}$ had sharply increased.

In this study, the stocks and experimental groups were kept in a refrigerated incubator in a humid environment of $25 \pm 1{ }^{\circ} \mathrm{C}$ and $40-60 \%$ throughout the experiments. In this way, the effect of temperature on the length of life was standardized.

In a study conducted by Fred and Timothy [24] on 10 Drosophila populations, it was found that within a nutrient medium with brewer's yeast, the length of life had increased once there was no metabolic waste. Therefore, the frequent renewal of the nutrient medium has a life-extending effect in this sense.

Also in this study conducted on food additives, the Drosophila instant medium of the flies included within all the groups were changed on the same day twice a week, and the metabolic wastes were disposed of from the environment.

The studies performed so far have suggested that the type of a nutrient affects the length of life in Drosophila. It is reported that in Drosophila, the development takes place normally within the nutrient medium containing $1 \%$ of agar at very low concentrations, and that the mortality rate remains at a lower level, while the mature ones almost never lay any eggs and do not survive longer under these circumstances. Whereas, it is argued that the males live the longest at an $8 \%$ - concentration, and that the least difference is seen in the length of life between the sexes. It was determined in Drosophila that only the sugared diet increased the mortality rate but reduced the egg- laying process; on the other hand, when the rate of brewer's yeast is increased more, the mortality rate and egg-laying increased along with it, as well [25]. The nutrition in Drosophila affects both the length of life in male and female individuals and the efficiency in the egg-laying process [26]. Hence, in this study, the standard Lewis instant medium was used throughout the experimental process. The amount of sugar, brewer's yeast, agar and cornflour used within this medium are known, and the medium is a standard one.

It was determined that the egg-laying process in $D$. melanogaster affected the length of life in a negative way and that the sterile females survived longer than the nonsterile ones [27]. In a study conducted on $D$. melanogaster, early mating and early egg-laying process were determined to have decreased the length of life [5, 28, 29]. Separately, it is known that the maternal age has also an impact on the length of life. For this reason, in this study, additives were administered into the larvae obtained as the result of mating the female and male individuals of the same age that had never mated before. As the result of this application, by also collecting the flies emerging from the pupa at 4-hour-intervals, they were prevented from mating with each other. Since all the individuals used during the experiments performed on the length of life had never mated before, there was no error in monitoring the population in numbers.

In a study conducted by Koç and Gülel [30], on $D$. melanogaster, it was pointed out that the metabolic rate in the individuals fed by the same type of nutrient at the same temperature but exposed to different photoperiodic conditions was different and that this situation affected the length of life in D. melanogaster, as well. In this study, however, while the D. melanogaster individuals used during the experiments were being transferred only in the course of the food-switching process, they were taken out of the incubation and were kept in the medium of dark incubation for 24 hours, thanks to which the effect of lighting on the length of life was tried to be eliminated.

Mating and egg-laying reproduction are the factors that affect the aging process. In general, it is reported that mating and egg-laying at higher levels reduce the survival percent of females [31]. In one of the studies conducted by Tatar et al., [32] it was stated that mating and egg-laying reproduction 
increased the mortality rate peculiar to age in the female bees of Callosobruchus maculates species and accelerated the senescence. In a study conducted on D. melanogaster, it was determined that when there was a decrease in the early egg reproduction, the mortality rates and the early mortality rates in females decreased, as well [33]. In a study conducted on D. melanogaster males, the reproductive process was found to have affected the mortality rate. According to this study, the mortality rates of the males that reproduced were more than those which did not [34]. In a similar study, mating was found to have shortened the length of life in male Drosophila [28]. In another study, on the other hand, the effect of mating on the length of life in the wild $D$. melanogaster species of Oregon and Canton S breeds was investigated. It was found that while the CS males that mated lived much longer than those which did not, the females that mated had shorter life spans compared to the virgin ones. Whereas similar results were also determined for the OR females, no difference could be found in males [35].

It is seen in the studies investigating the interaction between sexes and the length of life that Drosophila males are generally seen to have shorter life spans than the female ones. As the result of the study conducted by Lints et al., [36] it was concluded that the females usually survived longer than the male ones. Yet, the studies conducted on various Drosophila breeds were seen to have weakened this generalization.

For instance, in a study conducted by Iliadi et al., [35] the D. melanogaster females of Oregon breed were determined to have survived much longer than the male ones. However, such a difference could not be observed in the Canton $\mathrm{S}$ breed researched in this matter. In a study conducted by Ünlü [18], on the other hand, the males of Oregon breed survived longer than the female ones, whereas the females of vermilion and miniature mutants lived longer than the male ones.

The genes on DNA, which is a molecule governing the cell, and thus, the organism, and several changes taking place on these genes have an impact on longevity. There are a number of studies conducted for the purpose of investigating the effect of genes on longevity. For example, in a study performed by Lin et al., [37] it was observed that the longevity had increased by $35 \%$ in a Drosophila mutant referred to as methuselah (mth), the life span of which was increased and made resistant to various stressors.

In a similar study, it was determined that the $m t h$ gene of D. melanogaster, in the $\mathrm{P}$ element insertion breed, had increased longevity. However, it was also pointed out that the $m t h$ gene of wild species also had a life-shortening effect, which was due to the negative pleiotropic effect of the gene [38]. One of the factors affecting the life span is the population density. In the studies conducted to research into the effects of the population density in Drosophila, the effects of the larval density in particular on the length of life of the mature individuals were investigated. In the studies conducted, it was found that the larval density during the premature phase had made the mature individuals to emerge late and in small sizes and had also caused the small individuals to survive longer than the normal ones. Thus, it was reported that with the increase in the larval density, the body size of the mature ones decreased, while their life span increased [39]. In contrast to these studies, Graves and Mueller [40] stated that the increasing population density would reduce the life span through several mechanisms, such as the decrease in nutritional sources, diseases and changes in the physical environment.

To summarize the results obtained from the whole study; it was determined as the result of administering all the food additives to Drosophila melanogaster that these substances caused deviations in the length of life and percentage of survival of Drosophila melanogaster species. Since the Drosophila melanogaster culture was prepared under optimum conditions and great care was taken in carrying out the processes of both medium changes and the experimental practices, we can consider that such deviations observed in consequence may have resulted from the food additives we used during this process. These substances may have negatively affected the length 
of life or the genes or enzymes regarding development. Such effects may lead to changes in the population density peculiar to the species by affecting all the vital activities, the developmental characteristics of the living creature and the egg efficiency. Even though these substances may not show any adverse effects in the short term, they can still create toxic effects for the organism by accumulating within the living body in the long term uses. As was also stated by Paracelsus, "All things are poisons, for there is nothing without poisonous qualities. It is only the dose which makes a thing poison".

\section{Acknowledgements}

This work was supported by the Cumhuriyet University (CUBAP, F-355).

\section{REFERENCES}

[1]. Potter CJ, Turenchalk GS, Xu T. Drosophila in cancer research. Trends in Genetics 2000; 16 (1): 33- 39.

[2]. Osaba L, Rey MJ, Aguirre A, Alonso A, Graf U. Evaluation of genotoxicity of captan, maneb and zineb in the wing spot test of Drosophila melanogaster: Role of nitrosation. Mutation Research 2002; 518 (1): 95-106.

[3]. Lehmann M, Franco A, de Souza Prudente Vilar K, Lukza Reguly M, de Andrade HH. Doxorubicin and two of its analohues are preferential inducers of homologous recombination compared with mutational events in somatic cells of Drosophila melanogaster. Mutation Research 2003; 539 (1-2): 167-175.

[4]. Arking R. Genetic and environmental determinants of longevity in Drosophila. Basic Life Sci. 1987; 42: 1-22.

[5]. Arking R, Buck S, Novoseltev VN, Hwangbo DS and Lane M. Genomic plasticity, energy allocations, and the extended longevity phenotypes of Drosophila. Ageing Research Reviews 2002; 1 (2): 209-228.

[6]. Bonilla E, Medina-Leendertz S, Díaz S. Extension of life span and stress resistance of Drosophila melanogaster by long-term supplementation with melatonin. Experimental Gerontology 2002; 37(5): 629-38.

[7]. Sarıkaya R, Çakır Ş, Solak K. Effects of food preservatives on the longevity of Drosophila melanogaster (mwhxflr), Kastamonu Education Journal 2006; 14: 173- 184.

[8]. Uysal H, Altun D, Aslan A. The effects of Lobarla pulmonaria(L.) Hoffm. on the longevity on Drosophila melanogaster. Turkish Science-Research Foundation 2009; 2 (3): 271- 276.

[9]. Uysal H, Semerdöken S, Çolak DA, Ayar A. The hazardous effects of the three natural food dyes on developmental stages and longevity of $D$. melanogaster. Toxicology and Industrial Health (2013) e-journal.

[10]. Ayar A, Uysal H, Altun D. The effects of cold shock on the longevity in Oregon $\mathrm{R}$ wild and Vestigial mutant of Drosophila melanogaster (Diptera: Drosophilidae). Ekoloji 2009; 74: 38-44.

[11]. Sarıkaya R, Solak K. Genotoxicity of benzoik acid Studied in the Drosophila melanogaster Somatic Mutation and Recombination Test (SMART). Gazi University Journal of Gazi Educational Faculty (GUJGEF) 2003; 23(3): 19-32.

[12]. Sarıkaya R, Çakır Ş. Genotoxicity testing of four food preservatives and their combinations in the Drosophila wing spot test. Environmental Toxicology And Pharmacology 2005; 20, 424-430.

[13]. Stallings DM, Hepburn DD, Hannah M, Vincent JB, O'Donnell J. Nutritional supplement chromium picolinate generates chromosomal aberrations and impedes progeny development in Drosophila melanogaster. Mutation Research 2006; 610 (1-2): 101-13.

[14]. Demir E, Kocaoğlu S, Kaya B. Genotoxicity testing of four benzyl derivatives in the Drosophila wing spot test. Food and Chemical Toxicology 2008; 46: 1034 - 1041.

[15]. Erciyas K, Sarıkaya R. Genotoxic evaluation of sodium fluoride in the Somatic Mutation 
and Recombination Test (SMART). Food and Chemical Toxicology 2009; 47: 2860 2862.

[16]. Sarıkaya R. Effects of food dyes in different concentrations on percentage of survival in Drosophila melanogaster ( $m w h \quad x$ flr). Süleyman Demirel University Journal of Natural and Applied Sciences 2010; 5 (1): $38-46$

[17]. Deepa PV, Priyanka V, Swarna R, Akshaya S. Genotoxicity of benzaldehyde in Drosophila melanogaster using the wing somatic mutation and recombination test (smart) and protein profiling. International Journal of Medical and Clinical Research 2012; 3(6): 195-198.

[18]. Ünlü H. Variable effects of some genes in the life span of Drosophila melanogaster. Turkish Journal of Biology 1991; 15: 124 131.

[19]. Bağcı G, Bozcuk AN. Effect of temperature and light on the life span of adult Drosophila. Turkish Journal of Biology 1991; 15: $1-8$.

[20]. Memmi BK, Ünlü H. The effects of short duration microwave exposure on the life span and the induction of sex-linked recessive lethal mutations in Drosophila melanogaster. Hacettepe J. of Biol. and Chem. 2007; 35(3): 173 -179.

[21]. Bağc1 G, Bağc1 H, Bozcuk AN. Effect of minimum temperature fluctuations on lifetime. Turkish Journal of Biology 1990; 14: 1 - 5 .

[22]. Setsini EA, Carlson JC, Allsopp R. The effects of ambient temperature on life span, lipid peroxidation, superoxide dismutase, and phospholipase A2 activity in Drosophila melanogaster. Experimental Gerontology 1991; 26: 385 - 395.

[23]. Economus AC, Lints FA. Developmental temperature and life span in Drosophila melanogaster. Gerontology 1986; 32 (1): 18-27.

[24]. Fred H, Timothy JB. An analysis of resouece allocation in response to dietary yeast in Drosophila melanogaster. Journal of Insect Physiology 1997; 43(8): 779-788
[25]. Good TP, Tatar M. Age-specific mortality and reproduction respond to adult dietary restriction in Drosophila melanogaster.

Journal of Insect Physiology 2001; 47: 14671473.

[26]. Carey JR, Liedo P, Harshman L, Zhang Y, Muller HG, Partridge L and Wang JL. Life history response of Mediterranean fruit flies to dietary restriction. Aging Cell 2002; 1 (2): 140-148.

[27]. Ueyama, M. and Fuyama, Y. Enhanced cost of mating in female sterile mutants of Drosophila melanogaster. Genes \& Genetic Systems 2003; 78 (1): 29-36.

[28]. Prowse $\mathrm{N}$ and Partridge L. The effects of reproduction on longevity and fertility in male Drosophila melanogaster. Journal of Insect Physiology 1997; 43(6): 501-512.

[29]. Novoseltsev VN, Novoseltseva JA, Boyko SI and Yashin AI. What fecundity patterns indicate about aging and longevity: Insights from Drosophila studies. Journals of Gerontology Series A-Biological Sciences and Medical Sciences 2003; 58 (6): 484-494.

[30]. Koç Y and Gülel A. Effects of photoperiod and the natural food quality on the preadult developmental time, adult longevity, fecundity and sex-ratio of Drosophila melanogaster Meigen, 1830. J. of Fac. of Agric., OMU 2006; 21(2): 204-212

[31]. Tatar M, Promislow DEL. Fitness costs of female reproduction. Evolution. 1997; 51(4), 1323-1326.

[32]. Tatar M, Carey JR, Vaupel JW. Long-term cost of reproduction with and without accelerated senescencein Callosobruchus maculatus: Analysis of age- specific mortality. Evolution 1993; 47(5), 1302 1312.

[33]. Sgro CM, Partridge L. A delayed wave of death from reproduction in Drosophila. Science 1999; 286: 2521-2524.

[34]. Miyo T, Charlesworth B. Age-specific mortality rates of reproducing and nonreproducing males of Drosophila melanogaster. Proc. R. Soc. Lond. B. 2004; 271: 2517-252 
[35]. Iliadi KG, Iliadi, NN, Boulianne GL. Regulation of Drosophila lifespan: Effect of genetic backround, sex, mating and social status. Experimental Gerontology 2009; 44: 546-553.

[36]. Lints FA, Bourgois M, Delalieux A, Stoll J, Lints CV. Does the female life span exceed that of the male: A study in Drosophila melanogaster. Gerontology 1983; 29(5): 336-352.

[37]. Lin YJ, Seroude L, Benzer S. Extended lifespan and stres resistance in the Drosophila methuselah. Science 1998; 282: 943-946.
[38]. Partridge L. Evolutionary theories of ageing applied to long-lived organisms. Experimental Gerontology 2001; 366: 641650.

[39]. Luckinbill LS, Clare MJ. A density threshold for the expression of longevity in Drosophila melanogaster. Heredity 1986; 56: 329-335.

[40]. Graves JL, Mueller LD. Population density effects on longevity. Genetica 1993; 91: 99109. 